\title{
EFEKTIVITAS UNDANG-UNDANG NOMOR 31 TAHUN 2014 TENTANG PELINDUNGAN SAKSI DAN KORBAN
}

\author{
Oleh: H. DUDUNG MULYADI, S.H., M.H)
}

\begin{abstract}
Legal protection is a form of service that must be provided by the government, the importance of legal protection against any member of the community is formed of Act Number 13 of 2006 on the Protection of Witnesses and Victims and has made changes to the Law No. 31 Year 2014 concerning Organization Witness and Victim Protection,

In this Act, is set on an institution that is responsible for handling the provision of protection and assistance of victims and witnesses, called the Witness Protection Agency (LPSK) the duty and authority to provide protection and assistance to witnesses and victims of the authority of the Agency in Law No. 31 of 2014 on Witness and Victim Protection Agency expanded. The scope of protection by the Agency is at all stages of the criminal justice process, in order to witness and / or victim feel safe when giving testimony or testimony, request the protection of the Agency carried out in several stages as well as the protection of witnesses and victims by the Agency.

Protection Award in the form of awards for Whistleblower and Justice Collaborator of great importance to the efforts to create a climate conducive to the disclosure of corruption in the context of community involvement.

Keywords : Efektivitas, The Agency.
\end{abstract}

\begin{abstract}
ABSTRAK
Perlindungan hukum merupakan suatu bentuk pelayanan yang wajib diberikan oleh pemerintah, pentingnya perlindungan hukum terhadap setiap anggota masyarakat dibentuk Undang-undang Nomor 13 Tahun 2006 tentang Perlindungan Saksi dan Korban dan telah dilakukan perubahan dengan Undang-Undang Nomor 31 Tahun 2014 tentang Lembaga Perlindungan Saksi dan Korban.

Dalam Undang-undang ini, diatur tentang sebuah lembaga yang bertanggung jawab untuk menangani pemberian perlindungan dan bantuan pada saksi dan korban, yang dinamakan Lembaga Perlindungan Saksi dan Korban (LPSK) yang bertugas dan berwenang untuk memberikan perlindungan dan bantuan kepada saksi dan korban kewenangan LPSK dalam Undang-Undang Nomor 31 Tahun 2014 tentang Lembaga Perlindungan Saksi dan Korban diperluas. Lingkup perlindungan oleh LPSK adalah pada semua tahap proses peradilan pidana, agar saksi dan/atau korban merasa aman ketika memberikan keterangan atau kesaksian, permohonan pemberian perlindungan dari LPSK dilakukan melalui beberapa tahap serta pemberian perlindungan saksi dan korban oleh LPSK.

Penghargaan Perlindungan dalam bentuk penghargaan bagi para Whistleblower dan Justice Collaborator sangat penting keberadaannya bagi upaya menciptakan iklim kondusif bagi pengungkapan tindak pidana korupsi dalam konteks pelibatan masyarakat.

Kata Kunci : Efetivitas, LPSK

*) Dosen Fakultas Hukum Universitas Galuh
\end{abstract}




\section{PENDAHULUAN}

Perlindungan hukum merupakan suatu bentuk pelayanan yang wajib diberikan oleh pemerintah untuk memberikan rasa aman kepada setiap warga masyarakat hal itu berdasarkan Undang-undang Dasar Negara Republik Indonesia Tahun 1945.

Apabila dikaji dari fungsi dan tujuan Hukum Pidana, fungsi dari Hukum Pidana merupakan bagian dari hukum pada umumnya yaitu untuk mengatur hidup kemasyarakatan atau menyelenggarakan tata tertib dalam masyarakat. Sedangkan dari tujuannya untuk menegakkan tertib hukum, melindungi masyarakat hukum manusia serta memberikan rasa takut untuk melakukan perbuatan pidana dan mendidik orang yang melakukan perbuatan pidana supaya sadar sehingga menjadi orang yang lebih baik. Untuk itu perlindungan hukum terhadap setiap masyarakat sangat penting dan apabila perlindungan hukum ditiadakan maka kemungkinan dari perbuatan yang dilarang akan menghambat atau menghalangi cita-cita bangsa Indonesia, yaitu masyarakat adil dan makmur, sehingga merupakan bahaya bagi keselamatan masyarakat.

Pentingnya perlindungan hukum terhadap setiap anggota masyarakat inilah yang menjadi salah satu alasan dibuat Undang-undang Nomor 13 Tahun 2006 tentang Perlindungan Saksi dan Korbandan telah dilakukan perubahan dengan Undang-Undang Nomor 31 Tahun 2014 tentang Lembaga Perlindungan Saksi dan Korban.

Di dalam Undang-undang ini, diatur pula tentang sebuah lembaga yang bertanggung jawab untuk menangani pemberian perlindungan dan bantuan pada saksi dan korban, yang dinamakan Lembaga Perlindungan Saksi dan Korban (LPSK) yang bertugas dan berwenang untuk memberikan perlindungan dan bantuan kepada saksi dan korban. Lingkup perlindungan oleh LPSK adalah pada semua tahap proses peradilan pidana, agar saksi dan/atau korban merasa aman ketika memberikan keterangan atau kesaksian.

Kenyataannya posisi saksi dan korban rentan terhadap teror dan intimidasi, tidak terlindungi oleh hukum dan terisolir dari masyarakat luas. Itulah sebabnya, saksi maupun korban cenderung tidak mau bicara karena posisi publiknya justru dapat menempatkan dirinya sebagai "korban untuk kedua kalinya" karena pengungkapan peristiwa yang dialami, didengar, maupun diketahuinya. 
Peranan saksi dalam setiap perkara pidana sangat penting karena kerap keterangan saksi dapat mempengaruhi dan menentukan kecenderungan keputusan hakim. Seorang saksi dianggap memiliki kemampuan yang dapat menentukan kemana arah keputusan hakim. Berdasarkan hal ini memberikan efek kepada setiap keterangan saksi selalu mendapatkan perhatian yang sangat besar baik oleh pelaku hukum yang terlibat didalam persidangan maupun oleh masyarakat pemerhati hukum. Oleh karena itu, saksi sudah sepatutnya diberikan perlindungan hukum karena dalam mengungkap suatu tindak pidana saksi secara sadar mengambil resiko dalam mengungkap kebenaran materil.

Dalam perkembangannnya Undang-Undang Lembaga Perlindungan Saksi dan Korban mengalami perubahan yaitu dengan dikeluarkannnya Undang-Undang Nomor 31 Tahun 2014 tentang Perlindungan Saksi dan Korban. Undang-undang Nomor : 13 tahun 2006 akhirnya telah mengalami perubahan menjadi Undang-undang Nomor : 31 Tahun 2014, yang memuat beberapa perubahan ketentuan dari Undangundang sebelumnya disesuaikan dengan perkembangan hukum di indonesia. Secara singkat, undang- undang Nomor : 31 Tahun 2014 memiliki tujuh point penting perubahan undang-undang tersebut. Pertama, penguatan kelembagaan LPSK, kedua, penguatan kewenangan LPSK, ketiga, perluasan subyek perlindungan, keempat, perluasan pelayanan perlindungan terhadap korban, kelima, peningkatan kerjasama dan koordinasi antar lembaga, keenam, pemberian penghargaan dan penanganan khusus yang diberikan terhadap saksi pelaku, ketujuh, perubahan ketentuan pidana termasuk tindak pidana yang dilakukan korporasi.

Pemenuhan hak-hak korban tindak kejahatan sudah lama diakui oleh Negara Republik Indonesia, sejak Undang-Undang Perlindungan Saksi dan Korban Nomor 13 Tahun 2006 diundangkan. Melalui revisi Undangundang 13 Tahun 2006, yaitu UndangUndang Nomor 31 Tahun 2014, semakin banyak hak-hak korban tindakkejahatan yang diakui oleh negara.

Perbedaan paling signifikan dalam pemenuhan hak-hak korban yang tercantum dalam revisi Undang-undang Nomor 31 Tahun 2014 adalah hak pemulihan psikososial dan psikologis. Selain itu dalam Undang-Undang Perlindungan Saksi dan Korban yang baru diundangkan pada akhir tahun 
2014 lalu tersebut juga mencantumkan mengenai tata cara pemberian hak atas kompensasi bagi korban tindak pidana pelanggaran HAM berat, terorisme, dan hak atas restitusi.

\section{KEWENANGAN LEMBAGA PERLINDUNGAN SAKSI DAN KORBAN}

Dalam

memberikan

perlindungan, lembaga perlindungan saksi dan korban (LPSK) memiliki kewenangan yang telah di tentukan dalam Pasal 5 Undang-Undang Perlindungan Sanksi dan Korban (LPSK).

Kewenangan lembaga

perlindungan saksi dan korban dimulai dari Pasal 5 ayat (1) Saksi dan Korban yang menegaskan bahwa saksi dan korban berhak:

a. Memperoleh perlindungan atas keamanan pribadi, Keluarga, dan harta bendanya, serta bebas dari Ancaman yang berkenaan dengan kesaksian yang akan, sedang, atau telah diberikannya;

b. Ikut serta dalam proses memilih dan menentukan bentuk perlindungan dan dukungan keamanan; c. memberikan keterangan tanpa tekanan;

d. Mendapat penerjemah;

e. Bebas dari pertanyaan yang menjerat; f. Mendapat informasi mengenai perkembangan kasus;

g. Mendapat informasi mengenai putusan pengadilan;

h. Mendapat informasi dalam hal terpidana dibebaskan;

i. Dirahasiakan identitasnya;

j. Mendapat identitas baru;

k. Mendapat tempat kediaman sementara;

I. Mendapat tempat kediaman baru;

m.Memperoleh penggantian biaya transportasi sesuai dengan kebutuhan;

n. Mendapat nasihat hukum;

o. Memperoleh bantuan biaya hidup sementara sampai batas waktu Perlindungan berakhir; dan/atau

p. Mendapat pendampingan.

Sedangkan dalam ayat (2) dalam penjelasannya dijelaskan bahwa LPSK memberikan perlindungan terhadap Saksi dan/atau Korban tindak pidana dalam kasus tertentu sesuai dengan Keputusan LPSK. Dalam ayat ini menjabarkan jenis-jenis tindak pidana tertetu yang dimaksud dalam UndangUndang Lembaga Perlindungan Saksi dan Korban Pasal 5 ayat (2) yaitu tindak pidana pelanggaran HAM berat, Tindak Pidana Korupsi, Tindak Pidana Pencucian Uang, Tindak Pidana Terorisme, Tindak Pidana Perdagangan Orang, Tindak Pidana Narkotika, Tindak 
Pidana Psitropika, Tindak Pidana Seksual terhadap anak dan Tindak Pidana lain yang mengakibatkan posisi saksi dan korban dihadapkan pada situasi yang membahayakan jiwa. (Basuki Haryono; 2016:5).

$$
\text { Selanjutnya dalam ayat }
$$

disebutkan bahwa Selain kepada Saksi dan/atau Korban, hak yang diberikan dalam kasus tertentu sebagaimana dimaksud pada ayat (2), dapat diberikan kepada Saksi Pelaku, Pelapor, dan ahli, termasuk pula orang yang dapat memberikan keterangan yang berhubungan dengan suatu perkara pidana meskipun tidak ia dengar sendiri, tidak ia lihat sendiri, dan tidak ia alami sendiri, sepanjang keterangan orang itu berhubungan dengan tindak pidana.

Selain Pasal 5 adapula kewanangan dari LPSK yang diperluas yaitu dalam Pasal 6 mengenai bantuan yang harus diberikan oleh LPSK terhadap Korban dan/saksi. Dalam Pasal 6 Undang-Undang Nomor 31 Tahun 2014 ini menjelaskan bahwa pemberian bantuan yang diberikan oleh LPSK yaitu mengenai bantuan medis dan Rehabilitasi Psikologikal dan Psikologi.

Bantuan dalam hal medis ini dapat dijabarkan bahwa bantuan yang diberikan untuk memulihkan kesehatan fisik Korban, termasuk melakukan pengurusan dalam hal Korban meninggal dunia misalnya pengurusan jenazah hingga pemakaman. Rehabilitasi psikososial yang dimaksud dalam Undang-Undang Nomor 31 Tahun 2014 tentang Lembaga Perlindungan Saksi dan Korban ini yaitu adalah semua bentuk pelayanan dan bantuan psikologis serta sosial yang ditujukan untuk membantu meringankan, melindungi, dan memulihkan kondisi fisik, psikologis, sosial, dan spiritual Korban sehingga mampu menjalankan fungsi sosialnya kembali secara wajar, antara lain LPSK berupaya melakukan peningkatan kualitas hidup Korban dengan melakukan kerja sama dengan instansi terkait yang berwenang berupa bantuan pemenuhan sandang, pangan, papan, bantuan memperoleh pekerjaan, atau bantuan kelangsungan pendidikan. Selanjutnya dalam penjelasan Pasal 6 menyebutkan pula yang dimaksud dengan rehabilitasi psikologis adalah bantuan yang diberikan oleh psikolog kepada Korban yang menderita trauma atau masalah kejiwaan lainnya untuk memulihkan kembali kondisi kejiwaan Korban.

Dalam Undang-Undang LPSK pun mengatur tentang Kompensasi yang di atur secara tegas dalam Pasal 7, yang berarti LPSK pun mempunyai 
kewenangan dalam pemberian kompensasi dimana hal tersebut dianggarkan dari anggaran LPSK, pemberian kompensasi diberikan terhadap korban pelanggaran HAM Berat dan korban tindak pidana terorisme dan hanya di berikan terhadap korban dalam putusan yangtelah mempunyai kekuatan hukum tetap. Hal ini bertujuan untuk melindungi terhadap korban yang dianggap telah menderita akibat tindak pidana yang dimaksud.

Sehingga dapat di lihat bahwa pemerintah bukan hanya memberikan keadilan berupa pemidanaan terhadap orang yang melakukan tindak pidana, tetapi juga memberikan perlindungan terhadap korban yang dianggap telah dirugikan akibat perbuatan tersebut berupa kompensasi. Dimana kompensasi dibayarkan oleh LPSK terhadap korban berdasarkan putusan pengadilan yang telah memperoleh kekuatan hukum tetap.

Serupa dengan itu dalam Pasal 7A mengatur tentang pemberian restitusi bagi korban, restitusi disini diberikan atas dasar ganti kerugian atas kehilangan kekayaan atau penghasilan, ganti kerugian yang ditimbulkan akibat penderitaan yang berkaitan langsung sebagai akibat tindak pidana dan/atau penggantian biaya perawatan medis dan/atau psikologis. pengajuan restitusi dapat dilakukan sebelum ataupun sesudah putusan. Jika permohonan restitusi dilakukan sebelum putusan pengadilan yang telah memperoleh kekuatan hukum tetap maka LPSK dapat mengajukan Restitusi kepada penuntut umum untuk dimuat dalam tuntutannya namun jika restitusi tersebut dimintakan setelah putusan maka restitusi tersebut dapat dimintakan kepada Pengadilan. Dalam hal ini terhadap tindak pidana yang dapat dimintakan restitusi diatur menurut keputusan Lembaga Perlindungan Saksi dan Korban.

Kewenangan

Lembaga

Perlindungan Saksi dan Korbanpun di perluas dalam Pasal 10 yaitu Saksi, Korban, Saksi Pelaku, atau Pelapor tidak dapat dituntut secara hukum, baik pidana maupun perdata atas laporan atau kesaksian yang akan sedang, atau telah diberikannya, kecuali kesaksian atau laporan tersebut diberikan tidak dengan iktikad baik. Dalam hal terdapat tuntutan hukum terhadap Saksi, Korban, Saksi Pelaku, dan/atau Pelapor atas kesaksian dan/atau laporan yang akan, sedang, atau telah diberikan, tuntutan hukum tersebut wajib ditunda hingga kasus yang ia laporkan atau ia berikan kesaksian telah diputus oleh pengadilan dan memperoleh kekuatan hukum tetap. 
Lebih lanjut dari kewenangan Lembaga Perlindungan Saksi dan Korban terdapatdalam Pasa 12A yang menyatakan bahwa LPSK berwenang untuk mendapatkan informasi atas perkembangan kasusnya dari aparat penegak hukum, berwenang mengubah identitas, menngelolah rumah aman yaitu tempat kediaman sementara atau tempat kediaman baru yang dirahasiakan sesuai dengan standar yang ditentukan oleh LPSK serta melakukan penilaian untuk pemberian kompensasi.

Terhadap anak korban/saksi yang diberikan perlindungan oleh Lembaga Perlindunngan Saksi dan Korban semua perlindungan yang diberikan tersebut harus adanyanya izin dari orang tua. Namun dalam keadaan tertentu perlindungan tersebut dapat diberikan tanpa adanya izin dari orang tua namun izin tersebut diberikan oleh Ketua Pengadilan Negeri hal tersebut diatur dalam Pasal 29 A UndangUndang Nomor31 Tahun 2014 tentang Perlindungan Saksi dan Korban.

Lembaga Perlindungan Saksi dan korban dapat melakukan penghentian perlindungan jika dirasa korban/saksi yang diberikan perlindungan tersebut ternyata dalam pelaksanaannya memberikan keterangan palsu, sumpah palsu, dan permufakatan jahat seperti tegas tercantum dalam Pasal 32 UndangUndang Nomor31 Tahun 2014 tentang Perlindungan Saksi dan Korban. Lembaga perlindungan saksi dan korban pun berwenang melakukan kerjasama dengan istansi lain yang berkaitan dengan tindak pidana tersebut atau aparat hukum yang berwenang (Pasal 36 Undang-Undang Nomor31 Tahun 2014 tentang Perlindungan Saksi dan Korban).

Lembaga Perlindungan Saksi dan Korban dapat melahirkan kewenangan jika saksi dan korban yang bersangkutan melakukan permohonan terhadap Lembaga Perlindungan Saksi dan Korban (LPSK), sehingga dapat dikatakan bahwa Lembaga Perlindungan Saksi dan Korban sifatnya pasif, tidak memberikan perlindungan terhadap saksi ataupun korban yang tidak meminta perlindungan.

\section{ALUR PERMOHONAN PERLINDUNGAN SAKSI DAN KORBAN}

Permohonan untuk meminta dilakukannnya perlindungan bagi korban atau saksi dalam suatu tindak pidana dapat dilakukan dengan cara melakukan permohonan langsung atau melalui alat komunikasi formal. Permohonan dapat diajukan oleh pelaku, korban saksi, atau 
ahli, kuasa hukumnya atau pejabat yang berwenang.

Tahapan dimulai dengan melakukan registrasi kemudiaan dilakukan pemeriksaan secara formil terhadap kelengkapan administrasi dalam hal ini memerlukan waktu 30 (tiga puluh) hari hasil dari pemeriksaan ini ada dua yaitu lengkap atau tidak lengkapnya pernyaratan administrasi.

Jika ternyata kelengkapan administrasi ini tidak lengkap maka dilakukan proses investigasi demi terpenuhinya kelengkapan dokumen. Namun jika ternyata kelengkapan tersebut dinyatakan lengkap maka dilanjutkan kembali pada tahap telaah substansi yaitu penelaahan isi dari permohonan perlindungan saksi dan korban, dalam hal ini memerlukan waktu 7 (tujuh) hari. Putusan LPSK akan disampaikan secara tertulis pada pemohon.

Setalah dilakukan hal tersebut maka diadakan rapat paripurna anggota dimana didalamnya membahas tentang diterima atau ditolaknya permohonan perlindungan saksi korban tersebut, dengan mempertimbangkan hal-hal yang harus diperhatikan, tetang layak tidaknya pemberian perlindungan tersebut. Hal-hal yang dipertimbangkan dalam permohonan perlindungan oleh LPSK yaitu : a. Sifat penting Hasil dari rapat paripurna tersebut bisa menghasilkan hasil di terima atau se keterangan pemohon;

b. Tingkat ancaman yang dialami pemohon;

c. Rekam medis dan psikologis pemohon;

d. Rekam jejak kejahatan yang pernah dilakukan pemohon.

Permohonan perlindungan saksi dan korban dapat diterima dengan alasan bahwa permohonan tersebut telah memenuhi syarat formil dan materil yang telah dipenuhi dalam permohonan tetrsebut. Dalam hal diterimanya permohonan tersebut maka melahirkan kewenangan bagi Lembaga Perlindungan Saksi dan Korban untuk melakukan perlindungan terhadap saksi dan korban yang dimaksud. Perlindungan tersebut dapat berupa perlindungan Fisik dan hukum, perlindungan terhadap pemenuhan hak prosedural atau berupa bantuan kompensasi dan restitusi.

Sedangkan permohonan perlindungan saksi dan korban yang dimohonkan kepada LPSK diputuskan ditolak jika dalam rapat paripurna anggota tersebut ternyata telah disepakati bahwa permohonan tersebut tidak memenuhi syarat formil dan materil yang dianggap bukan merupakan 
kewenangan Lembaga Perlindungan Saksi dan Korban. Penolakan permohonan tersebut ditegaskan dengan dikeluarkannnya surat pemberitahuan yang ditujukan kepada pemohon.

Kewenangan yang dilahirkan dari diterimanya permohonan perlindungan terhadap saksi dan korban tersebut tercantum dan ditegaskan dalam Undang-Undang Nomor 31 Tahun 2014 tentang Lembaga Perlindungan Saksi dan Korban atas perubahan Undang-Undang Nomor 13 Tahun 2006 tentang Perlindungan Saksi dan Korban.

Dari uraian tersebut dapat disimpulkan bahwa dalam melakukan permohonan perlindungan saksi dan korban kepada Lenmbaga Perlindungan Saksi dan Korban (LPSK) harus melalui beberapa tahap, tidak dapat langsung di terima begitu saja tanpa melalui tahapan-tahapan yang telah ditentukan.

IV. PENGHARGAAN

DARI LEMBAGA PERLINDUNGAN SAKSI DAN KORBAN

Penghargaan Perlindungan

dalam bentuk penghargaan bagi para Whistleblower dan Justice Collaborator sangat penting keberadaannya bagi upaya menciptakan iklim kondusif bagi pengungkapan tindak pidana korupsi dalam konteks pelibatan masyarakat. Penghargaan layak diberikan sebagai penegasan bahwa yang bersangkutan telah berjasa bagi upaya penegakan hukum, implikasinya bilamana terdapat penghargaan terhadap mereka masyarakat yang lain dapat berani juga mengungkapkan suatu tindak pidana kepada penegak hukum.

Bagi Whistleblower yang tidak tersangkut sebagai pelaku, penghargaan terhadap mereka telah diatur dalam peraturan perundangan. Salah satu diantaranya adalah PP Nomor 71 Tahun 2000 dan Pasal 10A Undang-undang Nomor 13 tahun 2006 jo Undang-undang Nomor 31 Tahun 2014.

Perlindungan dalam bentuk penghargaan bagi Justice Collaborator dapat berupa keringanan penjatuhan pidana, pembebasan bersyarat, remisi tambahan, dan hak narapidana lain sesuai Perundang-undangan yang berlaku apabila Saksi Pelaku yang bekerjasama adalah seorang narapidana.

\section{Untuk}

memperoleh penghargaan berupa keringan penjatuhan pidana, LPSK memberikan rekomendasi secara tertulis kepada penuntut umum untuk dimuat dalam tuntutannya kepada hakim. Untuk memperoleh penghargaan berupa 
pembebasan remisi tambahan, dan hak narapidana lain, LPSK memberikan rekomendasi secara tertulis kepada menteri yang menyelenggarakan urusan pemerintahan di bidang hukum.

Dalam hal pemberian perlindungan dalam bentuk penghargaan bagi Justice Collaborator dalam Tindak Pidana Korupsi secara teksnis dilakukan sesuai ketentuan dalam Peraturan Bersama sebagai berikut:

a. Permohonan diajukan oleh pelaku sendiri kepada Jaksa Agung atau pimpinan KPK;

b. LPSK dapat mengajukan rekomendasi terhadap saksi pelaku yang bekerjasama untuk kemudian dipertimbangkan oleh Jaksa Agung atau Pimpindan KPK;

c. Permohonan memuat identitas saksi pelaku yang bekerjasama, alas an dan bentuk penghargaan yang diharapkan;

d. Jaksa Agung atau pimpinan KPK memutuskan untuk memberikan atau menolak penghargaan yang dilakukan sesuai dengan ketentuan yang berlaku. (Sigit Artantojati; 2012; 56).

Selanjutnya dalam hal Jaksa Agung atau Pimpinan KPK mengabulkan permohonan penghargaan, Penuntut Umum wajib menyatakan dalam tuntutannya mengenai peran yang dilakukan oleh Justice Collaborator dalam membantu proses penegakan hukum agar dapat menjadi pertimbangan hakim dalam menjatuhkan putusan.Kemudian dalam hal penghargaan berupa remisi dan/atau pembebasan bersyarat maka permohonan diajukan oleh saksi pelaku yang bekerjasama, Jaksa Agung, Pimpinan KPK dan/atau LPSK kepada Menteri Hukum dan Hak Asasi Manusia untuk kemudian diproses sesuai peraturan perundang- undangan yang berlaku.

Bagi saksi pelaku yang bekerjasama yang dilindungi dapat memperoleh:

1. Pemisahan tempat penahanan atau tempat menjalani pidana antara saksi pelaku dengan tersangka, terdakwa dan/atau narapidana yang diungkap tindak pidana;

2. Pemisahan pemberkasan antara berkas saksi pelaku dengan berkas tersangka dan terdakwa dalam proses penyidikan, dan penuntutan atas tindakan yang diungkap dan atau

3. Memberikan kesaksian di depan persidangan tanpa berhadapan langsung dengan terdakwa yang diungkap tindak pidananya;

4. Keringanan penjatuhan pidana; 
5. Pembebasan bersyarat, remisi tambahan, dan hak narapidana lain sesuai dengan ketentuan peraturan perudang-udangan bagi saksi pelaku yang berstatus narapidana.

\section{PENUTUP}

1. Dalam Undang-Undang Nomor 31 Tahun 2014 tentang Lembaga Perlindungan Saksi dan Korban kewenangan LPSK diperluas, seperti yang ditegaskan dalam Pasal 5, Pasal 6, Pasal 7, Pasal 9, Pasal 10, Pasal 12, Pasal 29, Pasal 32 dan Pasal 36.

2. Permohonan perlindungan saksi dan korban kepada Lembaga Perlindungan Saksi dan Korban (LPSK) dapat dilakukan oleh pelopor, saksi, korban, ahli, keluarga atau kuasanya atau pejabat yang berwenang. Permohonan tersebut harus melalui beberapa tahap, tidak dapat langsung di terima begitu saja tanpa melalui tahapan-tahapan yang telah ditentukan. Hasil dari permohonana tersebut dapat berupa diterimanya permohonan atau berupa ditolak permohonan Perlindungan Saksi dan Korban tersebut.

3. Penghargaan Perlindungan dalam bentuk penghargaan bagi para Whistleblower dan Justice
Collaborator sangat penting keberadaannya bagi upaya menciptakan iklim kondusif bagi pengungkapan tindak pidana korupsi dalam konteks pelibatan masyarakat.

\section{DAFTAR PUSTAKA}

Abdulah, Edi., Muhadar., Thamrin Husni. 2010. Perlindungan Saksi dan Korban dalam Sistem Peradilan Pidana. Surabaya. PMN.

Adami, Chazawi. 2008. Hukum Pembuktian Tindak Pidana Korupsi. Bandung. PT. Alumni.

Waluyo, Bambang. 2011. Viktimologi Perlindungan Korban dan Saksi. Jakarta. Sinar Grafika.

Dina Zenita, 2006, Mengenal Perlindungan Saksi di Jerman: Indonesia Corupption Watch.

Arif Mansur,Dikdik. 2008. Urgensi Perlindungan Korban dan Kejahatan Antara Norma dan Realita, Jakarta: Raja Grafindo Persada.

Fuad Usfa. 2006. Pengantar Hukum Pidana, Malang: UPT Penerbitan Universitas Muhammadiyah Malang.

Widodo Eddyono,Supriyadi. 2007. Lembaga Perlindungan Saksi dan Korban di Indonesia : Sebuah Pemetaan Awal, Jakarta: Indonesia Corupption Watch.

Sigit Artantojati, 2012, Perlindungan Terhadap Saksi Pelaku Yang Bekerjasama (Justice Callaborators) Oleh Lembaga Perlindungan Saksi Dan Korban 


$$
\begin{aligned}
& \text { (LPSK), Tesis, Program Studi } \\
& \text { Magister (S2) Ilmu Hukum } \\
& \text { Universitas Indonesia. }
\end{aligned}
$$

\section{Perundang-undangan}

Kitab Undang-Undang Hukum Pidana (KUHP).

Undang-undang Nomor 8 Tahun 1981 tentang Kitab Undang-undang Hukum.

Undang-Undang Nomer 31 Tahun 2014 Tentang Perlindungan Saksi dan Korban Acara Pidana.

Peraturan Pemerintah Nomor : 44 Tahun 2008 Tentang Pemberian Kompensasi, Restitusi dan Bantuan Terhadap Saksi dan Korban.

SEMA Nomor : 4 Tahun 2011 Tentang Perlindungan Bagi Whistleblower dan Justice Collaborator. 